\title{
Predictive Value of Sense of Self-efficacy and Attitudes of High School Students for Their Resistance to Mathematics
}

\author{
Bengisu Koyuncu ${ }^{1, *}$, Pelin Dönmez ${ }^{2}$ \\ ${ }^{1}$ Department of Educational Science, Mimar Sinan Fine Arts University, Turkey \\ ${ }^{2}$ Math Teacher, 34755, Istanbul, Turkey
}

Copyright $\bigcirc 2018$ by authors, all rights reserved. Authors agree that this article remains permanently open access under the terms of the Creative Commons Attribution License 4.0 International License

\begin{abstract}
This study aimed to determine the power of sense of self-efficacy in and attitudes toward math in predicting resistance to mathematics for high school students. In accordance with the aims of the study, a correlational survey model was used to determine covariance between the variables. The data for this study were collected through surveys given to $10^{\text {th }}$ graders in 2016 spring semester. The students who were administered the surveys were chosen using simple random sampling. 831 students participated in the study (413 females with $49.70 \%$ and 418 males with $50.30 \%$ ). Three surveys were used for data collection: The Resistance Scale for High School Students (RSHSS), Math Self-Efficacy Survey and Math Attitudes Survey. Pearson correlation, means, standard deviation and simple linear regression were performed for data analyses. The significance level was accepted to be .01 for the analyses used in the study. According to the findings, there is a significant correlation at -.24 level between students' sense of self-efficacy in math and their resistant behavior toward math; a significant correlation at -.27 level $(p<0.05)$ between their attitude toward math and resistant behavior toward math. According to the regression analyses, sense of self-efficacy in math accounts for six percent of the variance for resistant behavior toward math and attitudes toward math account for seven percent of the variance for resistant behavior toward math.
\end{abstract}

Keywords Resistance, Resistance to Mathematics, Self-efficacy, Attitudes

\section{Introduction}

A characteristic of Turkish education system is its test-based structure for transitioning to the next educational level. National tests such as LGS (High School Transfer Exam), YGS (Transition to Higher Education Examination) and LYS (Undergraduate Placement Exam) and international tests such as PISA (The Programme for International Student Assessment) and TIMMS (Trends in International Mathematics and Science Study) are considered to be the yardsticks for measuring the performance of the educational system as a whole and the performance of students, teachers and educational institutions in particular. Turkey's, i.e. Turkish students', performance in mathematics in tests of this order are evaluated as follows:

In 2012, Turkey ranked $31^{\text {st }}$ in the PISA test among 64 countries with a score of 448 in mathematics. In 2015, it ranked $50^{\text {th }}$ among 62 countries with a score of $420[1,2]$. Turkey ranked $35^{\text {th }}$ among 50 countries in TIMMS, another international test administered in 2011 and $2016[3,4,5]$. As for national tests, the mathematics score in LGS was 40.00 in 2015, 42.05 in 2016, and 50.55 in 2017 [6].

Taken as a point of departure when creating educational curricula since 2010, the STEM (Science-Technology-Engineering-Mathematics) wave necessarily emphasizes mathematics as a fundamental discipline for science and technology. The Turkish Council of Higher Education (YOK) dissertation database reveals that 1183 graduate dissertations addressed the teaching of mathematics in the last ten years, attesting to a difficulty about learning and teaching the area [7]. Also, parents demand that their children receive intensive private tutoring, which has led to an increase in classified ads for teaching mathematics. The widespread belief that learning mathematics is important and even indispensable is accompanied by the anxiety over the difficulty in learning it. The significance of mathematics classes for schools, teachers, and students as a group has an impact on students' opinions about and attitudes toward the classes. Inner factors such as anxiety, attitude, motivation, resistance, 
belief and self-efficacy are likely to affect perceptions of parents, administrators, teachers and students about mathematics.

Students generally define mathematics as difficult [8] and lose interest in the subject. Their reasons may vary: some find the syllabus too dense $[9,10]$; others complain that they are not given enough time to conceptualize and contextualize the topics $[11,12]$.

Teachers are expected to take into account individual differences among learners and develop effective teaching methods accordingly. They also have to deal with negative attitudes toward their person and the class they teach, which can become intensive and disorienting. The concept of "student resistance" is used in the literature to define many types of aggravating behaviors such as asking irrelevant questions to disrupt class, trying to humiliate the teacher, and failing to do homework [13]. Student resistance was first put forward as a concept by neo-Marxist theoreticians in 1970s, when studies focused on the reactions students displayed or should display against what they were offered in schools, which were defined as transformative tools of capitalism. These studies led to research in later years into student resistance, working class resistance to dominant upper classes [14, 15], behaviors of black students [16], and female students' struggle to exist in a male-dominated class. In the last 15-20 years, studies into student resistance have addressed the issue within the scope of class management, focusing on understanding and developing strategies for resistance behaviors without reference to students' social backgrounds $[17,18]$.

Actions students display in reaction to situations in the classroom that they do not like can basically be defined as "resistant behavior/resistance" [19,20]. Described as resistance, such behavior is generally harmful for the students themselves, their teachers, their classmates and the learning-teaching process, yet it may have positive outcomes as well. For example, a criticism that aims to humiliate the teacher when a student levels it her about her teaching methods may lead the teacher to question herself, to reflect on her methodology and finally to improve her teaching [20]. Still, teachers define all kinds of resistant behavior as disruptive [21]. Students may display numerous resistant behaviors toward teacher behavior, unequal roles in numerous group activities and school administration for its failure to meet their expectations as a whole $[21,22]$. The most prominent of these are the ones that stem from teachers. Students frequently become resistant when the teacher has unfair assessment and evaluation practices, she is indifferent to her subject/students/job, she displays aggressive behavior, she overloads students with information or the class is boring, incomprehensible or unsatisfactory [13, 22]. Among resistant student behaviors are offering advice to the teacher, blaming the teacher, skipping the class, 'pretending' to be doing, being intentionally unprepared for class, participating in the class involuntarily, defying the teacher, displaying disruptive behavior in class (e.g. make noise), making excuses, behaving like there were not a teacher present, comparing different classes, challenging the teacher, organizing other students in a negative sense, threatening to complain to the administration, saying he is not interested in the subject because the teacher is uninterested, behaving as he wishes, and slandering the teacher $[19,20]$. Resistant behavior can be directly related to learning, and in the context of school can be either a result or a solution. Students tend to display resistant behavior when they cannot understand/learn the subject [23] or when the subject is beyond their level of comprehension [13] so that they could close the gap socially [23]. Moreover, students may resort to resistant behavior and refuse to learn to gain social acceptance or ensure that they are cared about [23,24]. Brookfield [25] considers low self-efficacy as one of the reasons for refusing to learn (in addition to fear of the unknown, learning per se, the teaching method, low interest in the subject, teaching style of the teacher, dislike for the teacher, etc.).

The first of the two independent variables in this study, self-efficacy expresses one's belief in one's capabilities when carrying out a task $[26,27,28]$. Since its coinage, the term has been a research area in as varied fields as education, business, athletics, careers, health and wellness [29]. Sense of self-efficacy affects a student's academic achievement, his preferred ways of learning, the time he spends on a task and his engagement [30,31]. Compared to others, students with high sense of self-efficacy accept academic assignments more readily, spend more time on them and attain success in the end [28, 27, 34, 32]. A student's sense of self-efficacy in a subject results from four variables and their interaction. The first of these variables is a student's personal experiences about the subject area, the tests, quizzes etc. The second is concerned about the experiences of the peers regarded as role models about the subject. The third is related to the narratives of the surrounding people such as the family, friends at school and teachers about whether he can be successful in the subject area. The final variable that forms beliefs of self-efficacy is a person's own feelings, attitudes etc. [28, $35,31]$. Sense of self-efficacy starts first to form with the family context and continue to develop among peers and at school in response to the attitudes of friends, role models, and teachers [32]. Although self-efficacy is defined as specific to a particular area, it is considered to be partly general by numerous theoreticians as well as Bandura himself because it has the potential to influence other areas. Therefore, scales developed to measure self-efficacy can be both specific and general at the same time teachers [29]. Many research studies indicate that the sense of self-efficacy has an impact of student motivation and development in academic contexts [33,31]. A high sense of self-efficacy in a subject area increases academic 
achievement, use of cognitive abilities and test scores [34]. A teacher's sense of self-efficacy in teaching and class management affect classroom atmosphere, which in turn affects students' sense of self-efficacy in the class. If the teacher has a low sense of self-efficacy, the students are likely to have low self-efficacy as well. Besides, low a sense of self-efficacy in a school as a whole lead to a decrease in students' sense of self-efficacy $[35,29]$.

The second independent variable of this study is attitudes toward mathematics. Attitude ranks first among factors teachers consider crucial in failure to learn mathematics [36]. In its broadest sense, attitude can be defined as "a mental, emotional and behavioral reactionary predisposition a person develops toward himself or toward an object, social issue or event in his environment based on his experiences, knowledge, emotions and drives" [37, p. 13]. Definitions of attitude in the literature toward mathematics [38] are developed as suggested in the definition above by replacing the object with mathematics. As can be understood from the definition, attitude is composed of cognitive, effective and kinetic elements. A cognitive element refers to ideas and knowledge about mathematics; an affective element, to negative or positive feelings toward mathematics; and a kinetic element, to experiences about mathematics [39, 37]. Attitude is a variable that affects achievement and engagement in mathematics. Studies both confirm $(40,41,42]$ and reject [43] the correlation between attitude and achievement [44, 45]. Attitude and achievement do not predict one another but they have effects on each other. Attitude develops with the effect of the environment even without taking a math course. This has an effect on achievement; achievement in class also has an effect of attitude [46]. The effect of attitude on mathematics takes place less through achievement than student's engagement with math [47]. An individual's negative attitudes toward a situation are often the result of negative past experiences. The individual who has developed a negative attitude toward an object/situation tends to avoid it, distances himself from it, or damage it [37]. Accordingly, negative student attitudes toward math can stem from personal experiences such as past low grades, inability to understand the topic or negative teacher behavior. Such a negative attitude toward math can lead to resistant behaviors such as disrupting the class, harming the teacher, or refusing to learn.

As explained above, one of the sources of self-efficacy is the individual's experiences about the subject, tests, assignments and study effort [28, 35, 31]. Experiences about a subject matter are also one of the main sources of the attitudes [37[. Negative experiences, namely low scores, inability to do homework assignments and failure to understand the topic, cause sense of self-efficacy in the subject to decrease [29] and negative attitudes to increase [37]. Referred to as sources of sense of self-efficacy and attitudes in the literature, negative past experiences are also stated among factors that lead to resistant behaviors [13,
22]. Despite such a theoretical relationship, there is no study that has addressed the relationship between self-efficacy beliefs/attitudes and resistant behaviors. To fill this gap in the literature, this study aimed to determine the effect of sense of self-efficacy and attitudes toward math on resistant student behavior toward math.

\section{Methodology and Material}

\subsection{Research Model}

The aim of the study was to determine the value of sense of self-efficacy and attitudes toward mathematics in predicting resistance to mathematics for high school students. In accordance with the aims of the study, a correlational survey model was used from among quantitative research models which aimed to determine the existence and/or extent of covariance between two or more variables [48]. The dependent variable of the study was resistant student behaviors toward math, while the independent variables were sense of self-efficacy in math and attitudes toward math.

\subsection{Research Sample}

The data for this study were collected through scales given to $10^{\text {th }}$ graders in Anatolian high schools in Beylikdüzü, Bakırköy, Kadıköy and Umraniye districts of Istanbul in spring semester in 2016. A total of 831 students, selected through simple random sampling, participated in the study, 413 of whom were female $(49.70 \%)$, and 418 were male $(50.30 \%)$.

\subsection{Data Collection Tools}

To collect data for the study, the Resistance Scale for High School Students (RSHSS), Math Self-Efficacy Survey, and Math Attitudes Survey were used.

\subsubsection{Resistance Scale for High School Students (RSHSS)}

The scale, developed by Yüksel and Şahin [49], was used to measure students' resistance to math. The scale consists of 26 five-point Likert-type questions $(1=$ Strongly Agree, $2=$ Agree, $3=$ =Not Sure, $4=$ Disagree, and 5=Strongly Disagree). The scale has five constructs and a reliability coefficient of .85. The Cronbach Alpha was found to be .83 for this study. The increase obtained in the scale shows that there is an increase in resistant student behavior. In its original, the scale measures general resistant behaviors of students; the students who participated in this study were asked to consider only their math classes and math teachers when answering the questions in the survey.

\subsubsection{Math Self-Efficacy Survey}

The students' sense of self-efficacy toward math was 
collected through Math Self-Efficacy Survey developed by Umay [50]. The survey includes 14 items, and the five-point Likert-type scale was scored as: $1=$ Strongly Agree, 2=Agree, 3=Not Sure, 4=Disagree, and 5=Strongly Disagree. The survey had three factors, which were defined as (1) mathematical sense of self, (2) awareness of behavior in mathematical subjects, and (3) the ability to transform math into life skills. The original reliability coefficient of the survey was .88. The Cronbach Alpha was found to be .85 for this study. The increase in the score obtained in the survey shows that there is an increase in students' sense of self-efficacy in math.

\subsubsection{Math Attitudes Survey}

The students' attitudes toward math were collected through Math Self-Attitudes Survey developed by Önal [51]. The survey includes 22 items, and the five-point Likert-type scale was scored as: 1= Strongly Agree, 2=Agree, 3=Not Sure, 4=Disagree, and 5=Strongly Disagree. The survey had four factors, namely, engagement, anxiety, effort and necessity. The reliability coefficient of the survey as measured by Önal [51] was .90. The Cronbach Alpha was found to be .89 for this study. The increase in the score obtained in the survey shows that there is an increase in students' attitudes toward math.

\subsection{Administration of the Data Collection Tools}

The data collection tools were administered to second year students in high schools in the spring semester of 2015-2016 education year. The reason why second year students were chosen was that they had acquired the feeling of being a high school student the previous year and they had started the high school math education program. Also, it was assumed that the students must have internalized the experiences they had as they had been preparing for the LGS in secondary school and developed insights into their process of learning math. Therefore, they were expected to answer the survey questions in a more informed manner. Before the surveys were implemented, the aim of the study was explained to the school administration, the mathematics department and the students. The students were then asked whether they would volunteer to participate in the surveys and only the volunteers were invited. Finally, the participants were asked to write only their gender and first name on the surveys so that ethical rules could be observed.

\subsection{Data Analysis}

First, Pearson correlation analysis was performed to determine the relationship between the dependent variable (resistance) and independent variables (self-efficacy-attitude). The mean and standard deviation values were also examined for the three variables. Then simple linear regression was performed to determine whether students' sense of self-efficacy in math and their attitudes toward math could predict their resistant behavior toward math. The data were analyzed using SPSS 22.0. The significance level was accepted to be .01 for the analyses used in the study.

\section{Findings}

Kolmogorov-Smirnov test was first used to determine whether the data about the variables in the study were normally distributed. The analyses showed that the data obtained from the three measurement tools had normal distribution $(\mathrm{p}>0.05)$.

One of the preconditions for performing simple and multiple regression analyses on variables is whether there is a meaningful relationship between the variables. Besides, for multiple regression analysis, it is necessary that the correlation between the variables should not be .70 and above [52]. The results of the Pearson correlation analysis performed to determine the relationship between the dependent and independent variables of the study are given in Table 1.

Table 1. Correlation between dependent and independent variables

\begin{tabular}{|c|c|c|}
\hline Variables & Self-efficacy & Attitude \\
\hline \multirow{2}{*}{ Attitude } & .74 & - \\
\hline \multirow{2}{*}{ Resistance } & $\mathrm{p}<0.01$ & -.27 \\
& -.24 & $\mathrm{p}<0.05$ \\
\hline
\end{tabular}

Table 1 shows that there is a significant positive correlation between students' self-efficacy and their attitude toward math $(\mathrm{r}=0.74, \mathrm{p}<0,01)$. There is a significant negative correlation between level of students' resistant behavior toward math and their sense of self-efficacy in math $(\mathrm{r}=-0.24, \mathrm{p}<0,05)$ and between resistant behavior and attitudes toward math $(r=-0.24$, $\mathrm{p}<0,05)$. These findings show that preconditions are established for performing regression analyses between the variables. However, multiple regression analysis was not performed because the correlation between self-efficacy and attitude turned out to be higher than .70 .

Table 2 shows the mean values and standard deviations for the scores obtained from the variables of resistance, attitude and self-efficacy in math classes.

Table 2. Descriptive statistics for the independent variables

\begin{tabular}{|c|c|c|c|c|c|}
\hline & $\mathrm{N}$ & $\begin{array}{c}\text { Lowest } \\
\text { Value }\end{array}$ & $\begin{array}{c}\text { Highest } \\
\text { Value }\end{array}$ & Mean & $\begin{array}{c}\text { Std. } \\
\text { Deviation }\end{array}$ \\
\hline Resistance & 829 & 46 & 124 & 90,29 & 15,18 \\
\hline Self-efficacy & 829 & 14 & 70 & 38,32 & 10,20 \\
\hline Attitude & 829 & 22 & 104 & 60,68 & 14,46 \\
\hline
\end{tabular}

According to Table 2, the mean score of the students' responses in the resistance scale is 90.29 . The lowest score on the scale is 26; the highest is 130 ; and the mean is 78 . The fact that the mean score is 90.29 , shows that the students' resistant behavior toward math is quite high. The lowest score on the self-efficacy survey is 14; the highest is 
70; and the mean is 42. According to this result, self-efficacy score is below the mean. Finally, the lowest, highest, and mean scores on the attitude survey are 22, 110, and 61 , respectively. The results show that the students' attitudes are slightly below the mean.

The results of correlation analyses performed to Table 3 and Table 4.

Table 3. Simple regression analysis about whether a sense of self-efficacy in mathematics class can predict resistance to math

\begin{tabular}{|c|c|c|c|c|c|c|c|}
\hline Variables & $\mathrm{B}$ & Standard Error $_{\beta}$ & $\mathrm{R}$ & $\mathrm{R}^{2}$ & Standardized $_{\beta}$ & $\mathrm{t}$ & $\mathrm{F}$ \\
\hline Self-efficacy & -.351 & .050 & .236 & 0.056 & -.236 & $6.974^{*}$ & $48.643^{*}$ \\
\hline
\end{tabular}

$* \mathrm{p}<0.01, \mathrm{~N}=829$

An analysis of the results in Table 3 shows that a sense of self-efficacy in second year high school students can predict their resistance to math in a significant way $(\mathrm{F}(1,827)=48.643, \mathrm{p}<0.01)$. According to this result, $6 \%$ of the total variance about resistance can be explained through self-efficacy.

Table 4. Simple regression analysis about whether attitudes toward math can predict resistance to math

\begin{tabular}{|c|c|c|c|c|c|c|c|}
\hline Variables & $\mathrm{B}$ & $\begin{array}{c}\text { Standard } \\
\text { Error }_{\beta}\end{array}$ & $\mathrm{R}$ & $\mathrm{R}^{2}$ & Standardized $_{\beta}$ & $\mathrm{t}$ & $\mathrm{F}$ \\
\hline Attitude & -.281 & .035 & .268 & 0.072 & -.269 & $7.996^{*}$ & $63.931^{*}$ \\
\hline
\end{tabular}

$* \mathrm{p}<0.01, \mathrm{~N}=829$

An analysis of the results in Table 4 shows that attitudes of second year high school students toward math can predict their resistance to math in a significant way $(\mathrm{F}(1,827)=63.931, \mathrm{p}<0.01)$. According to this result, $7 \%$ of the total variance about resistance can be explained through attitude.

\section{Conclusion and Discussion}

Student resistance is one of the problems teachers face during teaching process. Actions that students think beforehand to prevent themselves and others from learning are called acts of resistance [20]. Resistant behavior stem mostly from negative behavior of the teacher and peers or the make-up of the school program [19, 21]. As can be seen, resistance is fundamentally the student's reaction to negative behaviors he is exposed to. Self-efficacy and attitude stems from the student's personal experiences and in response to his interactions with his peers, family and teachers [29, 31, 39]. Both self-efficacy and attitude have the potential to affect the student's academic success [40,33] and his behavior in class [37]. A student with a low sense of self-efficacy and negative attitude toward math is likely to have little interest in the subject. It is likely that a student who has to follow a lesson he does not like or understand will display resistant behavior, and even more so if he does not like the teacher as well.

The findings in this study support the theoretical underpinnings stated above. According to the findings, there is a significant negative correlation at .24 level between students' sense of self-efficacy in math and their resistant behavior toward math. Although the finding does not express a relatively high value, it still shows that there is a correlation between the variables. According to these findings, it can be said - although partly - that when the student's sense of self-efficacy decreases his resistant behavior increases. The regression analysis shows that sense of self-efficacy in math can be said to predict six percent of resistant behavior toward math. According to this result, it can be explained that the students who developed self-efficacy skills regulating their own learning showed less resistance behavior. Therefore, students with high sense of self-efficacy accept academic assignments more readily, spend more time on them and attain success in the end $[35,27,34,32]$. The self-efficacy perception affects mathematical success positively, which is greater than the effects of other variables on mathematical success $[53,54,55]$. 
There is a significant negative correlation at .27 level between attitude toward math, which is the other independent variable of this study, and resistant behavior toward math. The findings show that when the students' attitudes turn negative toward math a partial increase takes place in their resistant behavior. The results of the regression analysis indicate that attitude toward math can be said to predict seven percent of resistant behavior toward math. Attitude is composed of cognitive, effective and kinetic elements. A cognitive element refers to ideas and knowledge about mathematics; an affective element, to negative or positive feelings toward mathematics; and a kinetic element, to experiences about mathematics [39;37]. Attitude is one of the variables affecting mathematics achievement and engagement in mathematics. For this reason, if the student's attitude toward mathematics is negative, it can be said that the higher resistance have. There are various studies showing that the relationship between attitude and success $[40,41,42]$. The effect of attitude on mathematics takes place less through achievement than student's engagement with math [47]. The fact that the individual is in a negative attitude towards a particular situation is mostly a result of past negative experiences. Thus, it can be said that there is a relationship between attitude and resistance.

It is a fact that both self-efficacy and attitude have an effect on resistance, though not very high. Students' sense of self-efficacy and attitudes toward the subject should be taken into account when possible reasons are suggested for resistant behavior such as rejecting to learn, skipping class, criticizing the teacher, displaying disruptive behavior, and organizing other students against the teacher.

Based on the results of this study, both the self-efficacy perception and the attitude were found to have effects on resistance, not too great. As a result, we can say that sense of self-efficacy in math and attitudes toward math are two variables that can partly predict high school students' resistant behavior toward math. When dealing with resistant behavior, it is necessary that activities should be carried out that aim to increase self-efficacy and bring about positive attitudes. Future studies should focus on various variables that may account for resistant behavior and affect learning as well as how these variables may predict such behavior. This study can also be replicated for other grades in high school and undergraduate students.

\section{REFERENCES}

[1] Milli Eğitim Bakanlığı (2015). PISA 2012 Research National Final Report. Ministry of National Education General Directorate of Measurement, Evaluation and Examination Services. Ankara. Online available from https://drive.google.com/file/d/0B2wxMX5xMcnhaGtnV2x $6 \mathrm{YWsyY2c/view}$
[2] Milli Eğitim Bakanlığı (2016). PISA 2015 National Report. Ministry of National Education General Directorate of Measurement, Evaluation and Examination Services. Ankara. Online available from http://pisa.meb.gov.tr/wp-content/uploads/2016/12/PISA20 15_Ulusal_Rapor1.pdf

[3] Milli Eğitim Bakanlığı (2014). TIMSS 2011 National Mathematics and Science Report 4th Grades. Ministry of National Education General Directorate of Innovation and Education Technologies. Ankara. Online available from http://timss.meb.gov.tr/wp-content/uploads/TIMSS-2011-4Sinif.pdf

[4] Milli Eğitim Bakanlığı (2014). TIMSS 2011 National Mathematics and Science Report 8th Grades. Ministry of National Education General Directorate of Innovation and Education Technologies. Ankara. Online available from http://timss.meb.gov.tr/wp-content/uploads/TIMSS-2011-8Sinif.pdf

[5] Milli Eğitim Bakanlığı (2016). TIMSS 2015 National Science and Mathematics Preliminary Report 4th and 8th Grades. Ministry of National Education General Directorate of Measurement, Evaluation and Examination Services. Ankara. Online available from http://timss.meb.gov.tr/wp-content/uploads/TIMSS_2015 Ulusal_Rapor.pdf

[6] Milli Eğitim Bakanlığı (2017). 2016, 2017 Eğitim Öğretim Yılı 2ç Dönem Merkezi Ortak Sınavı Test ve Maddeleri İstatistikleri. Haziran, Ankara. Online available from https://odsgm.meb_iys_dosyalar/2017_06/12171001_2017_ 2doYnem?Merkezi Ortak_SYnavY genel bilgiler_raporu -12.06.2017.pdf.

[7] YOK (2017). Council of Education System. Online available from https://tez.yok.gov.tr/ UlusalTezMerkezi/tarama.jsp

[8] Tall, D., \& Razali, M. R. (1993). Diagnosing students' difficulties in learning mathematics. International Journal of Mathematical Education in Science and Technology, 24(2), 209-222.

[9] Çiftci, O., Enver T. (2015). Teachers' Opinions about the Updated Secondary Mathematics Curriculum Turkish Journal of Computer and Mathematics Education Vol.6 No.2 (2015), 285-298 DOI: 10.16949/turcomat.15

[10] Sarier, Y., Anılan H. (2008). The sixth grade mathematics teachers' views about sub dimensions of mathematics curriculum. Ondokuz Mayıs Üniversitesi Eğitim Fakültesi Dergisi, 2008,(26),35-45

[11] Ayvaz, Y.Y. (1990). Statistical analysis of mathematics teaching in high school. Master Thesis, Dokuz Eylul University, Econometrics department, Izmir.

[12] Konur, K., Atlıhan S. (2012). Teachers' Views on Secondary Mathematics Curriculum Content Organization. Cumhuriyet International Journal of Education. Vol. 1, No 2, October, 2147-1606

[13] Kearney, P., Plax, T. G., Hays, E. R., \& Ivey, M. J. (1991). College teacher misbehaviors: What students don't like about what teachers say and do. Communication Quarterly, 39(4), 309-324.

[14] Apple, M.W. (1979).Ideology and curriculum. London: Routledge \& Kegan Paul. 
[15] Giroux, H. (1983). Theories of reproduction and resistance in the new sociology of education: A critical analysis. Harvard educational review, 53(3), 257-293.

[16] Cummins, J. (1989). Empowering minority students. California Association for Bilingual Education.

[17] McFarland, D. (2001). Student resistance: How to formal and informal organization of classrooms facilitate everyday forms of student defiance. American Journal of Sociology, 107 (3), 612-678.

[18] Moore, H. A. (2007). Student resistance in sociology classrooms: Tools for learning and teaching. Sociological Viewpoints, 23, 29.

[19] Burroughs NF, Kearney P, Plax TG (1989). Compliance-resistance in the college classroom. Communication Education, 38, 214-229.

[20] Richmond VP, McCroskey JC (1992). Power in the Classroom: Communication, Control, and Concern, Hillsdale, NJ: Erlbaum.

[21] Seidel, S. B., \& Tanner, K. D. (2013). "What if students revolt?" - considering student resistance: origins, options, and opportunities for investigation. CBE-Life Sciences Education, 12(4), 586-595.

[22] Goodboy, A. K., \& Bolkan, S. (2009). College teacher misbehaviors: Direct and indirect effects on student communication behavior and traditional learning outcomes. Western Journal of Communication, 73(2), 204-219.

[23] Cavell, H. (2011). Student Resistance in a Fifth-Grade Mathematics Class. Latinos/as and Mathematics Education: Research on Learning and Teaching in Classrooms and Communities, 63.

[24] Atherton, J. (1999). Resistance to learning: a discussion based on participants in in-service professional training programmes. Journal of Vocational Education and Training, $51(1), 77-90$.

[25] Brookfield, S. D. (2006). The skillful teacher. San Francisco: Jossey-Bass.

[26] Bandura, A. (1986). Social foundations of thought and action: A social cognitive theory. Englewood Cliffs, NJ: Prentice Hall.

[27] Bandura, A. (1988). Organisational applications of social cognitive theory. Australian journal of management, 13(2), 275-302.

[28] Bandura, A. (1994). Self-efficacy. In V. S. Ramachaudran (Ed.), Encyclopedia of human behavior (Vol. 4, pp. 71-81). New York: Academic Press. (Reprinted in H. Friedman [Ed.], Encyclopedia of mental health. San Diego: Academic Press, 1998).

[29] Schunk, D. H., \& Pajares, F. (2009). Self-efficacy theory. Handbook of motivation at school, 35-53.

[30] Pajares, F. (1997). Current directions in self-efficacy research. Advances in motivation and achievement, 10(149), $1-49$.

[31] Schunk, D. H. (1995). Self-efficacy and education and instruction. In J. E. Maddux (Ed.), Self-efficacy, adaptation, and adjustment: Theory, research, and application (pp.
281-303). New York: Plenum Press.

[32] Pajares, F., \& Schunk, D. (2001). The development of academic self-efficacy. Development of achievement motivation. United States, 7.

[33] Pajares, F. (1996). Self-efficacy beliefs in achievement settings. Review of Educational Research, 66, 543-578.

[34] Zimmerman, B. J. (1995). Self-efficacy and educational development. Self-efficacy in changing societies, 202-231

[35] Bandura, A. (1997). Self-efficacy: The exercise of control. New York: Freeman.

[36] Di Martino, P., Pantziara, M., Zhang, Q., Morselli, F., Heyd-Metzuyanim, E., \& Goldin, G. A. (2016). Attitudes, Beliefs, Motivation, and Identity in Mathematics Education. In Attitudes, Beliefs, Motivation and Identity in Mathematics Education (pp. 1-35). Springer International Publishing.

[37] Inceoğlu, M. (2010). Attitude, perception, communication. Beykent University Published. No: 69, 5. İstanbul.

[38] Zan, R., \& Di Martino, P. (2008). Attitude toward mathematics. Overcoming the Positive/Negative Dichotomy. The Montana Mathematics Enthusiast, 197-214

[39] Di Martino, P., \& Zan, R. (2003). What Does. International Group for the Psychology of Mathematics Education, 4, 451-458.

[40] Burstein, L. (1992). The analysis of multilevel data in educational research and evaluation. Review of Research in Education; 8, 158-223.

[41] Mensah, J. K., Okyere, M., \& Kuranchie, A. (2013). Student attitude toward mathematics and performance: Does the teacher attitude matter. Journal of Education and Practice, 4(3), 132-139

[42] Peker, M., \& Mirasyedioğlu, Ş. (2003). Lise 2. sınıf ögrencilerinin matematik dersine. Pamukkale Üniversitesi Eğitim Fakültesi Dergisi, 14(14), 157-166.

[43] Ma, X. and Kishor, N. (1997). Assessing the relationship between attitude toward mathematics and achievement in mathematics: A meta-analysis. Journal of Research in Mathematics Education 28: 26 - 47.

[44] Hannula, S. (2002). Attitude toward mathematics, emotions, expectations and values. Educational Studies in Mathematics, 49, 25-46.

[45] Larsen, J. (2013). Attitude in Mathematics: a thematic literature review. British Columbia: Simon Fraser University.

[46] Mcleaod, D. (1992). Research on affect in mathematics education: A reconceptualization. New York, Macmillan: National Council of Teachers of Mathematics.

[47] Midgley, C., Feldlaufer, H., \& Eccles, J. S. (1989). Student/teacher relations and attitudes toward mathematics before and after the transition to junior high school. Child development, 981-992.

[48] Büyüköztürk, Ş., Çakmak, E. K., Akgün, Ö. E., Karadeniz, Ş. \& Demirel, F. (2016). Scientific research methods. Ankara: PegemA Publish.

[49] Yüksel, S., Şahin, E. (2005). Resistance to the process of 
leaining and teaching among high school students who come from a lower socio-economic level. Education and Science 2005, Vol. 30, No 138 (52-62)

[50] Umay, A. (2001). Effect of primary school mathematics teacher's program on mathematics self-efficacy. Journal of Qafqaz University, 8(1), 1-8.

[51] Önal, N. (2013). A Study on the Development of a Middle School Students'Attitudes towards Mathematics Scale. Elementary Education Online. 12(4), 938 - 948. [Online]: http://ilkogretim - online.org.tr

[52] Köklü, N., Büyüköztürk, Ş., \& Çokluk-Bökeoğlu, Ö. (2007). Statistics for social sciences. Pegem A Publish.
[53] Taşdemir, C. (2012). Evaluating the mathematics selfefficacay levels of high school senior students in terms of some variables (The case of Bitlis). The Black Sea Journal of Science. Spring 3,2 (6), 39-50

[54] Çelik, E. (2012). Analysis of the relationship between mathematical problem solving success and metacognitive self-regulation, mathematical self-efficacy and self-evaluation decisions. Unpublished Doctoral Thesis, Marmara University, Istanbul.

[55] Doğan, N., Barıș, F. (2010). Levels of attitude, value, and self-efficacy variables predict students' mathematical achievements in the TIMSS-1999 and TIMSS-2007 exams. Journal of Measurement and Evaluation in Education and Psychology. 1(1), 44-50. 